\title{
SERVER-SIDE PROCESSING TECHNIQUES FOR OPTIMIZING THE SPEED OF PRESENTING BIG DATA
}

\author{
Heni Sulastri1; Alam Rahmatulloh²; Deri Kurnia Hidayat ${ }^{3}$ \\ 1,2,3Program Studi Informatika, Fakultas Teknik, Universitas Siliwangi \\ http://if.unsil.ac.id \\ 1henisulastri@unsil.ac.id, 2alam@unsil.ac.id,33deri.kurniahidayat@gmail.com
}

\begin{abstract}
Big data is the latest industry keyword to describe large volumes of structured and unstructured data that are difficult to process and analyze. Most organizations are looking for the best approach to managing and analyzing large volumes of data, especially in decision making. Large data causes the process of presenting information to be slow because all the large amounts of data must be displayed so that specific techniques are needed so that the presentation of information remains fast even though the data is already large. The website generally processes requests to the server, and then if the required data is available, the server will send all the data. This causes all processes to be based on the client-side. So that the client load becomes heavy in displaying all the data. In this study, server-side processing techniques will be applied so that all processes will be handled by the server and the data sent is not all direct but based on periodic requests from the client. The results of this study indicate the use of server-side processing techniques is more optimal. Based on the results of testing the data presentation speed comparison with server-side processing techniques $98.6 \%$ is better than clientside processing.
\end{abstract}

Keywords: Big Data, Client-side Processing, Data Tables, Server-side Processing

Intisari-Data besar merupakan kata kunci industri terbaru untuk menggambarkan volume besar data terstruktur dan tidak terstruktur yang sulit untuk diproses dan dianalisis. Sebagian besar organisasi mencari pendekatan terbaik untuk mengelola dan menganalisa volume data yang besar terutama dalam pengambilan keputusan. Data besar menyebabkan proses penyajian informasi menjadi lambat dikarenakan semua data yang banyak harus ditampilkan, sehingga diperlukan teknik tertentu agar penyajian informasi tetap cepat walaupun data sudah banyak. Website pada umumnya melakukan proses request kepada server, kemudian jika data yang diperlukan tersedia maka server akan mengirimkan semua datanya. Hal tersebut menyebabkan semua proses bertumpu pada sisi client. Sehingga beban client menjadi berat dalam menampilkan semua data tersebut. Pada penelitian ini akan diterapkan teknik server-side processing sehingga semua proses akan diatasi oleh server dan data yang dikirim tidak langsung semuanya, melainkan berdasarkan request secara berkala dari client. Hasil penelitian ini menunjukkan penggunaan teknik server-side processing lebih optimal. Berdasarkan hasil pengujian perbandingan kecepatan penyajian data dengan teknik server-side processing 98,6\% lebih unggul daripada client-side processing.

Kata Kunci: Big Data, Client-side Processing, Data Tables, Server-side Processing

\section{PENDAHULUAN}

Saat ini semenjak maraknya penggunaan slogan "paperless" menjadikan permasalah baru bagi dunia digital. Data digital semakin bertumpuk, hari ke hari database berjumlah ratusan ribuan bahkan jutaan. Para ahli, pakar maupun organisasi mencari alternatif dan pendekatan terbaik untuk mengelola data besar (big data)(Gartner, n.d.). Tren penyajian data yang paling banyak digunakan para developer adalah library datatable. Datatable menggunakan tipe koneksi half-duplex yaitu dua arah namum tidak bisa bersamaan (Husen, Rahmatulloh, \& Sulastri, 2019). Datatable merupakan library jquery javascript yang bertujuan untuk manipulasi data yang panjang menjadi data pendek, selain itu mempunyai fitur seperti pencarian, halaman, sorting dan tampilan data yang rapi, interaktif dan responsive (SpyMedia, 2019). Namun seiring dengan waktu, datatable menuai kontroversi bagi web developer. Penggunaan datatable menyebabkan kinerja suatu web menjadi lambat, hal ini dikarenakan datatable meload semua record yang ada pada suatu table dalam database. Ketika data masih sedikit tidak ada permasalahan, kinerja penyajian data berjalan normal. Namun ketika data besar hal ini menjadi kendala dan mengurangi kinerja sehingga performa web menjadi (Gope, Schlais, \& Lipasti, 2017). Untuk mengatasi permasalahan tersebut, akan dicoba penerapan teknik server-side processing sehingga dengan menitik beratkan semua proses pada sisi server akan membuat 
proses load data pada sisi client menjadi ringan dan cepat. Karena dengan teknik ini data besar tidak akan di load semua secara langsung, melainkan dibatasi oleh server berdasarkan dengan request yang dilakukan oleh client. Dengan demikian berapapun jumlah record yang akan disajikan tidak akan menjadi kendala lagi. Maka pada penelitian ini akan dicoba menguji kinerja penggunaan teknik server-side processing pada penyajian big data sehingga diharapkan kinerja web lebih optimal.

\section{BAHAN DAN METODE}

\section{A. Literatur Review}

Penelitian (Burd et al., 2006) membahas metode dan peralatan untuk membuat bahasa perantara atau file kode sumber dari sumber daya dari sisi server atau halaman web yang dinamis. Kode sumber kemudian dapat dikompilasi menjadi kelas yang dapat dieksekusi yang memungkinkan untuk pembuatan halaman web yang cepat untuk mengontrol objek yang menjalankan fungsi dari sisi server, termasuk render dari client.

Penelitian (Yannick Saillet, 2013) membahas sebuah metode tentang masukan ke komputer. Masukannya adalah terkait dengan frame aplikasi web dari sisi client browser. Metode ini mencakup pengkodean kontrol karakteristik dari input atau setidaknya sebagian dari permintaan ke aplikasi dari sisi server web.

Penelitian (Gope et al., 2017) membahas tentang PHP yang merupakan bahasa skrip dari sisi server yang dominan yang digunakan untuk menerapkan konten web dinamis. Kompilasi tepat waktu, seperti yang diterapkan di HipHopVM mutakhir Facebook, untuk membantu mengurangi kinerja PHP yang buruk, tetapi overhead yang besar tetap ada, terutama untuk aplikasi PHP berskala besar yang realistis.

Penelitian (Wang, Zender, \& Jenks, 2009) membahas tentang teknologi yang terus memungkinkan para ilmuwan untuk mengatur arsip baru dalam pengumpulan dan produksi data, mengintensifkan kebutuhan alat skala besar untuk secara efisien memproses dan menganalisa data besar yang terus meningkat.

Penelitian (Kersten \& Goedicke, 2010) membahas Pengujian berbasis browser adalah instrumen yang memadai untuk mendeteksi kesalahan dalam halaman web yang dihasilkan dengan mempertimbangkan proses sisi server dan kompleksitas jalur black-box.

\section{B. Kerangka Peneltian}

Dalam penelitian ini dibuat sebuah kerangka penelitian yang dijadikan pedoman untuk dapat menyelesaikan masalah terkait yang akan diteliti, digambarkan pada Gambar 1.

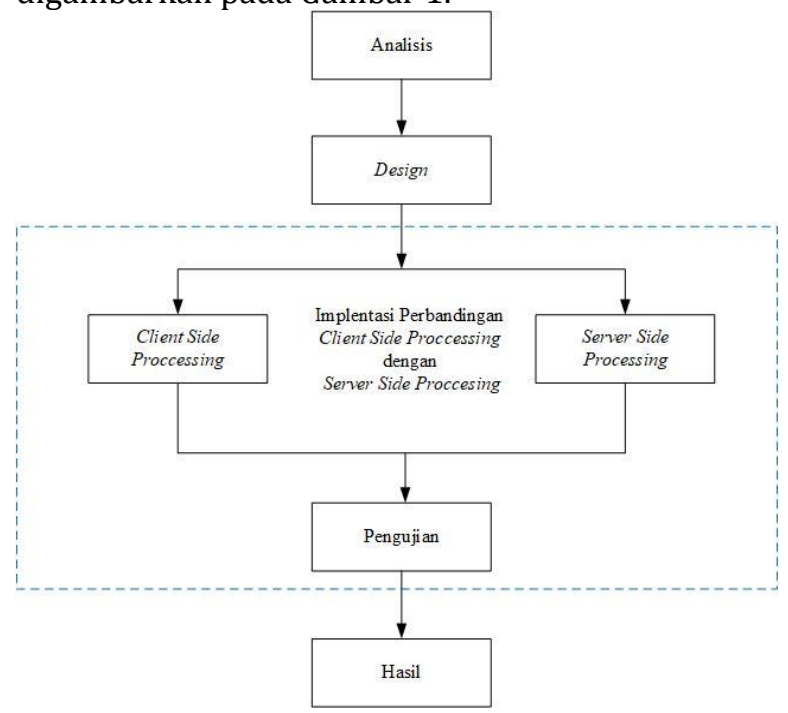

Sumber: (Sulastri, Rahmatulloh, \& Hidayat, 2019)

Gambar 1. Kerangka Penelitian

Gambar 1 merupakan kerangka metode penelitian, tahap pertama yaitu tahap analisis, tahap kedua adalah tahap design, tahap ketiga merupakan tahap implementasi perbandingan server-side processing dengan client-side processing, tahap selanjutnya adalah tahap pengujian dan tahap terakhir adalah hasil dan simpulan.

\section{HASIL DAN PEMBAHASAN}

\section{A. Analisis}

Dalam penelitian ini data yang diperlukan untuk pengujian data server-side processing dan client-side processing maka dibutuhkan data besar sebagai pengujian kedua proses tersebut. Big datasets didapatkan dari situs dataset archive yaitu https://archive.ics.uci.edu berupa file data bank yang berjumlah 45.211 row data.

1. Analisis Kebutuhan Fungsional

Analisis kebutuhan fungsional ini meliputi:

a) Penyajian data dari database.

b) Menampilkan informasi mengenai ukuran dan kecepatan pemanggilan data

2. Analisis Kebutuhan Non Fungsional

a. Analisis Perangkat Lunak / Software

Perangkat lunak yang digunakan untuk penyajian teknik server-side processing dan clientside processing saat ini adalah sebagai berikut :

1) Sistem Operasi : Microsoft Windows 10 Pro

2) Web Server : Apache 2.4.23

3) Database : Mysql 5.0.11

4) Web browser : Google Chrome 69.0.349

5) Text Editor : Sublime Text 3.1.1

b. Analisis Perangkat Keras / Hardware 
Perangkat keras yang digunakan untuk menerapkan teknik server-side processing saat ini spesifikasinya adalah sebagai berikut :

1) Processor dengan kecepatan minimal $1.5 \mathrm{GHz}$.

2) Memory RAM minimal 2GB

3) VGA minimal $512 \mathrm{MB}$

4) Harddisk dengan kapasitas penyimpanan minimal $500 \mathrm{~GB}$

5) Monitor dengan resolusi $1366 \times 768$

\section{B. Design}

Setelah melakukan analisis terhadap sistem, sesuai dengan kerangka penelitian maka tahap selanjutnya yang dilakukan adalah tahap desain. Dalam implentasi teknik server-side processing beberapa rancangan yang dibuat adalah flowchart alur sistem, struktur tabel database dan rancangan antar muka sistem.

Gambar 2 merupakan flowchart alur sistem untuk penerapan teknik server-side processing dimana dalam proses menampilkan data yang dipilih sesuai penyajian data tersebut dimulai dari memilih penyajian data kemudian data akan ditampilkan menurut penyajian data yang dipilih kemudian data akan ditampilkan dan dilakukan pengujian berdasarkan hasil tersebut.

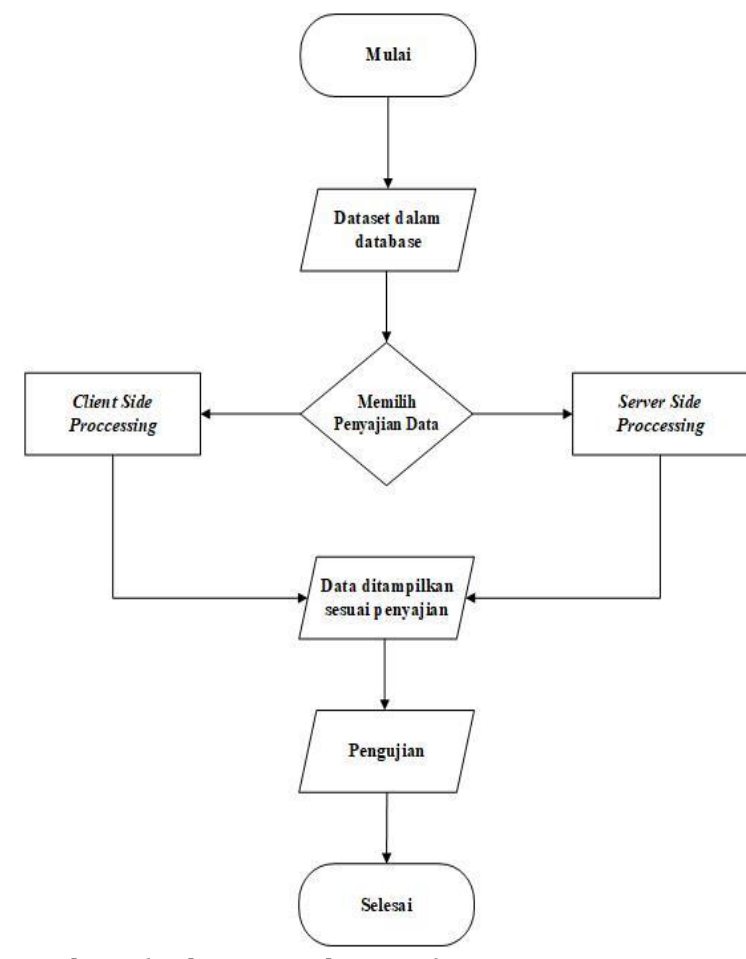

Sumber: (Sulastri et al., 2019)

Gambar 2. Flowchart Alur Sistem

C. Implementasi Perbandingan Cliet Side Processing dengan Server-side Processing

Gambar 3 merupakan tampilan antarmuka dashboard yang digunakan untuk memilih penyajian data, grafik pengujian dan tabel pengujian.

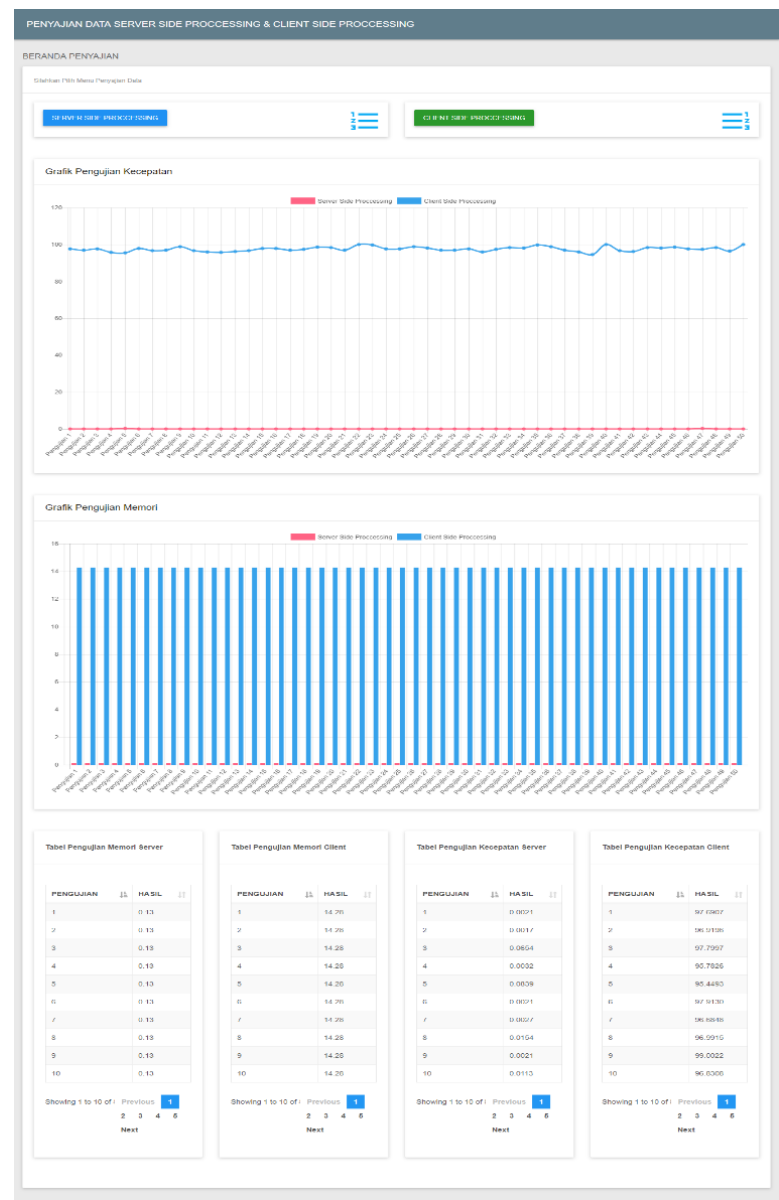

Sumber: (Sulastri et al., 2019)

Gambar 3. Tampilan Antar Muka Dashboard

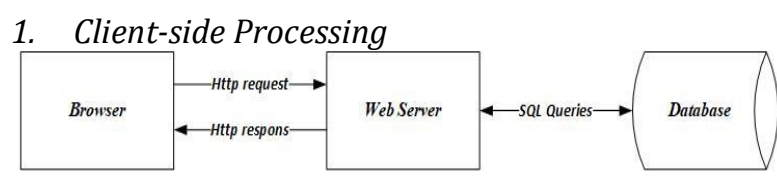

Sumber: (Sulastri et al., 2019)

Gambar 4. Client-side Processing

Gambar 4 merupakan alur client-side processing, browser melakukan request semua data ke web server yang terhubung ke database. Sebelum ditampilkan semua data akan diload terlebih dahulu oleh web browser, setelah data permintaan di dapatkan barulah web server akan mengirimkan data untuk ditampilkan di web browser.

Dalam mode pemrosesan sisi client, pengurutan data dalam tabel, penelusuran, paging, dan semua operasi pemrosesan data lainnya dilakukan di web browser. Ketika data yang diload oleh browser berjumlah sedikit, waktu pemrosesan tidak akan memerlukan waktu yang lama tetapi ketika data berjumlah sangat besar, proses load data akan 
memerlukan waktu yang sangat lama dan tidak efisien.

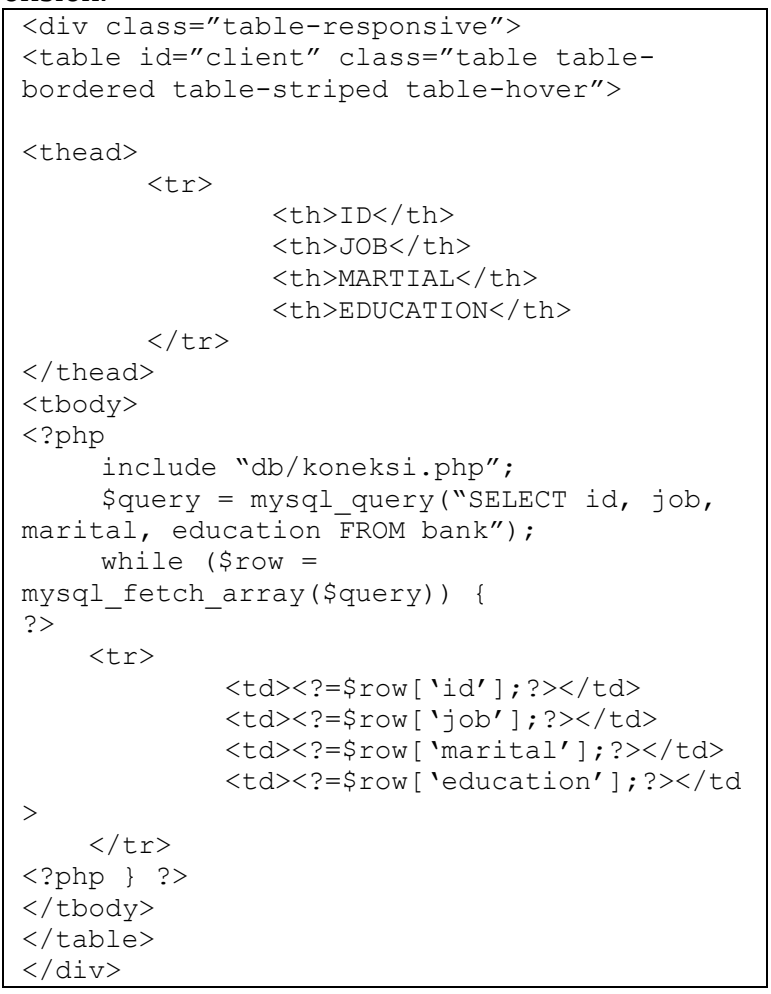

Sumber: (Sulastri et al., 2019)

Gambar 5. Contoh Sintaks Proses Penyajian Data Clientside Processing

Penjelasan gambar 5 yakni, perintah $<$ div class="table-responsive" $>$ digunakan agar tabel yang dibuat menjadi responsive artinya tabel tidak akan berantakan walaupun dibuka melalui device lain seperti smartphone yang memiliki resolusi layar yang lebih kecil. Perintah id="client" adalah id tabel yang nantinya akan digunakan untuk pemanggilan Jquery DataTables dengan pemanggilan javascript, sementara sintak class="table table-bordered table-striped tablehover" merupakan class tambahan dengan menggunakan bootstrap, class ini juga berfungsi untuk membuat baris tabel yang bergaya strip, efek hover pada tabel pada row tabel pada saat cursor mouse diletakan diatas row tabel. Perintah include "db/koneksi.php"; digunakan untuk mengkoneksikan ke database dan perintah \$query = mysql_query("SELECT id, job, marital, education FROM bank"); pemanggilan data yang terdapat di database untuk ditampilkan di web browser.

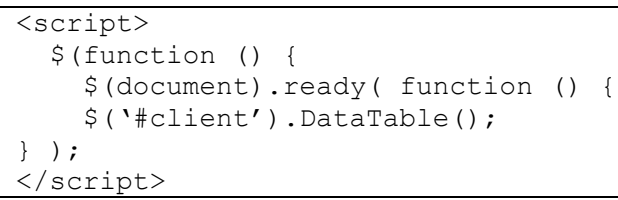

Sumber: (Sulastri et al., 2019)

Gambar 6. Contoh Sintaks Proses Menampilkan Jquery DataTables Client-side Processing
Penjelasan gambar 6 yakni, \$('\#client').DataTable(); adalah sintak untuk mengkonversi tabel HTML ke dalam format DataTables.

$<$ script

$\left.s r c=" j s / j q u e r y \cdot d a t a T a b l e s \cdot m i n \cdot j s^{\prime \prime}\right\rangle\langle/$ script $\rangle$

$<$ script

src $=" j s /$ dataTables.bootstrap.min.js" $></$ script

(nk href="css/dataTables.bootstrap.min.css" rel="stylesheet">

Sumber: (Sulastri et al., 2019)

Gambar 7. Contoh Sintaks Proses Pemanggilan Jquery DataTables

Gambar 7 merupakan sintak untuk bisa menggunakan DataTables dengan cara memanggil Plugin Jquery DataTables tersebut di direktori penyimpanan, ataupun bisa memanggilnya dengan cara online menggunakan server publik.

\section{Server-side Proceessing}

Pada tahap ini dijelaskan tahap pemrosesan DataTables menggunakan server-side processing.

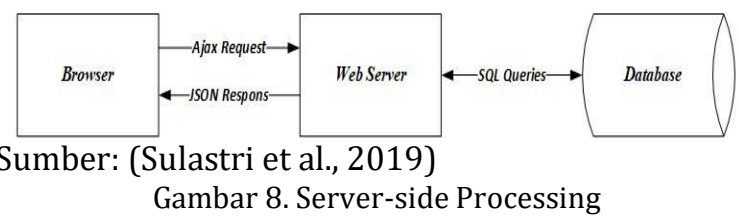

Gambar 8 merupakan alur server-side processing, ketika menggunakan pemrosesan sisi server, browser akan membuat permintaan Ajax baru ke server untuk setiap permintaan data yang diminta. Permintaan ini kemudian dikodekan ke format JSON yang akan mengirimkan respon dari script DataTables AJAX. Sehingga permintaan load data akan terasa ringan dikarenakan data akan melakukan request perhalaman ketika akan di tampilkan di web browser.

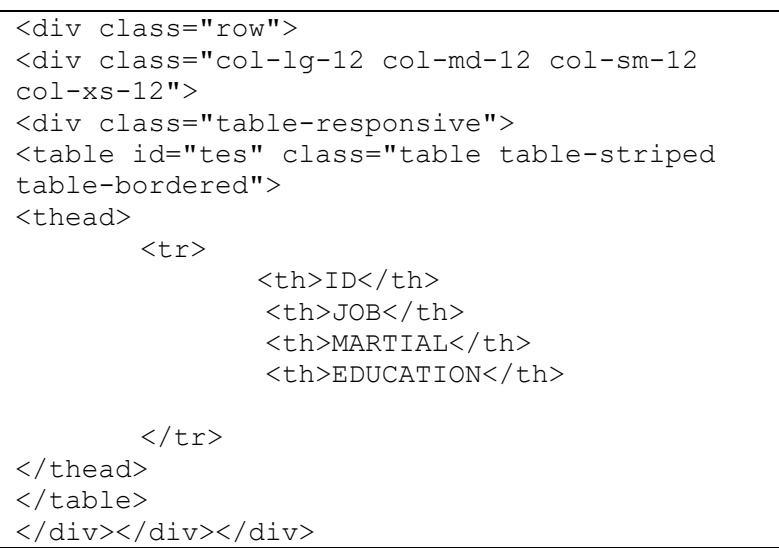

Sumber: (Sulastri et al., 2019)

Gambar 9. Contoh Sintaks Proses Penyajian Data Serverside Processing. 
Gambar 9 merupakan contoh sintak untuk penyajian data server-side processing, sama seperti penyajian data client-side processing tabel ini mempunyai id tabel yaitu id="tes" untuk pemanggilan DataTables. Seperti pada penjelasan alur proses server-side processing pada gambar 11, DataTables akan melakukan pemintaan $A J A X$ baru kepada server untuk pemanggilan data.

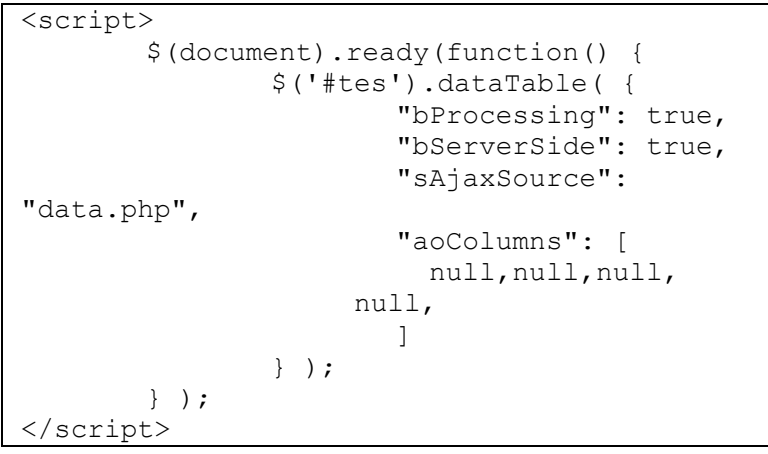

Sumber: (Sulastri et al., 2019)

Gambar 10. Contoh Sintaks Proses Menampilkan Jquery DataTables Server-side Processing

Gambar 10 merupakan contoh sintak untuk mengkonversi tabel kedalam bentuk DataTables dengan permintaan $A J A X$ baru untuk pemrosesan sisi server. Pada sintak javascript diatas, request $A J A X$ akan diarahkan ke file data.php yang bertugas menghandle server-side procesing dan untuk perintah null digunakan untuk menampilkan kolom yang diisikan data dari database.

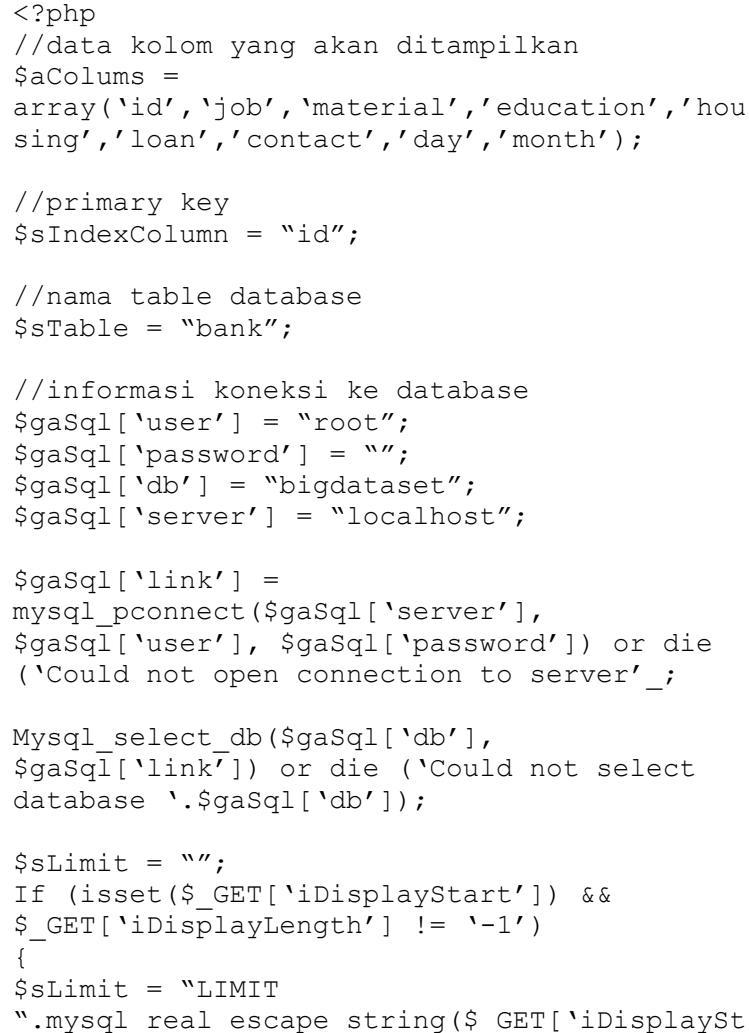

art']).",".mysql_real_escape_string(\$_GET['i DisplayLength']),

Sumber: (Sulastri et al., 2019)

Gambar 11. Sintak Pemrosesan Server-side Processing

Gambar 11 merupakan script yang bertugas untuk menghandle server-side processing dimana terdapat perintah \$aColumns = array ( 'id', 'job', 'marital', 'balance', 'housing', 'loan','contact', 'day', 'month' ); yang berfungsi untuk menampilkan kolom pada tabel. Perintah \$sIndexColumn = "id"; digunakan sebagai pemanggilan primary key, dalam database ini yang digunakan sebagai primary key adalah id. Perintah \$sTable ="bank"; digunakan sebagai pemanggilan tabel dari database.Perintah

\$gaSql['user']="root"; \$gaSql['password']="";\$gaS ql['db']="bigdataset"; \$gaSql['server']= "localhost"; digunakan sebagai koneksi database, dalam data ini database yang digunakan adalah bigdataset sementara perintah echo json_encode( \$output ); digunakan respon permintaan data untuk ditampilkan dan perintah lainnya adalah perintah bawaan yang disediakan DataTables untuk pemrosesan dari sisi server.

\section{Pengujian}

Pengujian dilakukan menggunakan tools JMeter dengan cara membandingkan penyajian data menggunakan client-side processing dengan serverside processing berdasarkan size, kecepatan load data dan Performance test. Percobaan dilakukan secara fair, yaitu dengan menggunakan database yang sama sebanyak 50 kali.

Tabel 1. Pengujian Server dan Client-Side

Processing Menggunakan Tools JMeter

\begin{tabular}{|c|c|c|c|c|}
\hline \multirow{2}{*}{ Pengujian } & \multicolumn{2}{|c|}{ Kecepatan (ms) } & \multicolumn{2}{|c|}{ Memory (bytes) } \\
\hline & Server & Client & Server & Client \\
\hline 1 & 679 & 65013 & 8610 & 2208377 \\
\hline 2 & 699 & 65062 & 8610 & 2207446 \\
\hline 3 & 667 & 64286 & 8610 & 2208488 \\
\hline 4 & 608 & 64311 & 8610 & 2209227 \\
\hline 5 & 588 & 64760 & 8610 & 2207872 \\
\hline 6 & 570 & 64967 & 8610 & 2207745 \\
\hline 7 & 632 & 64637 & 8610 & 2207479 \\
\hline 8 & 533 & 64592 & 8610 & 2207155 \\
\hline 9 & 554 & 64590 & 8610 & 2207752 \\
\hline 10 & 5151 & 64050 & 8610 & 2209042 \\
\hline 11 & 476 & 64700 & 8610 & 2207816 \\
\hline 12 & 497 & 64155 & 8610 & 2208626 \\
\hline 13 & 437 & 64559 & 8610 & 2207830 \\
\hline 14 & 458 & 64240 & 8610 & 2207727 \\
\hline 15 & 399 & 64138 & 8610 & 2207740 \\
\hline 16 & 359 & 64523 & 8610 & 2208026 \\
\hline 17 & 341 & 64222 & 8610 & 2208121 \\
\hline 18 & 303 & 64182 & 8610 & 2208025 \\
\hline 19 & 179 & 64021 & 8610 & 2207855 \\
\hline 20 & 324 & 64122 & 8610 & 2206916 \\
\hline 21 & 223 & 64266 & 8610 & 2208669 \\
\hline
\end{tabular}




\begin{tabular}{|c|c|c|c|c|}
\hline 22 & 204 & 64631 & 8610 & 2207156 \\
\hline 23 & 268 & 64430 & 8610 & 2207684 \\
\hline 24 & 960 & 64288 & 8610 & 2207309 \\
\hline 25 & 868 & 64371 & 8610 & 2208591 \\
\hline 26 & 1172 & 64736 & 8610 & 2207855 \\
\hline 27 & 814 & 64798 & 8610 & 2207824 \\
\hline 28 & 1199 & 64010 & 8610 & 2208133 \\
\hline 29 & 837 & 64616 & 8610 & 2208126 \\
\hline 30 & 937 & 64052 & 8610 & 2208412 \\
\hline 31 & 1118 & 64598 & 8610 & 2207765 \\
\hline 32 & 1183 & 64402 & 8610 & 2207885 \\
\hline 33 & 880 & 64484 & 8610 & 2208267 \\
\hline 34 & 1041 & 64828 & 8610 & 2207210 \\
\hline 35 & 1101 & 64507 & 8610 & 2208189 \\
\hline 36 & 1084 & 64899 & 8610 & 2207874 \\
\hline 37 & 1123 & 64364 & 8610 & 2207298 \\
\hline 38 & 1166 & 64695 & 8610 & 2207262 \\
\hline 39 & 342 & 64239 & 8610 & 2207482 \\
\hline 40 & 1274 & 63957 & 8610 & 2207651 \\
\hline 41 & 850 & 63965 & 8610 & 2207725 \\
\hline 42 & 953 & 64350 & 8610 & 2207518 \\
\hline 43 & 1019 & 64545 & 8610 & 2208014 \\
\hline 44 & 693 & 64924 & 8604 & 2207068 \\
\hline 45 & 1355 & 64687 & 8610 & 2208092 \\
\hline 46 & 1648 & 64014 & 8610 & 2208476 \\
\hline 47 & 2184 & 64782 & 8610 & 2207516 \\
\hline 48 & 2043 & 63930 & 8610 & 2207727 \\
\hline 49 & 3510 & 64719 & 8610 & 2207082 \\
\hline 50 & 4147 & 64334 & 8616 & 2207899 \\
\hline Rata Rata & 960,28 & 62651,02 & 8610 & 2207860 \\
\hline
\end{tabular}

Sumber: (Sulastri et al., 2019)

Tabel 1 menjelaskan riwayat pengujian performance test menggunakan tools JMeter, pengujian ini dilakukan sebanyak 50 kali percobaan. Dari hasil pengujian performance test didapatkan nilai rata-rata $62651,02 \mathrm{~ms}$ kecepatan load data dan 2207860 bytes penggunaan memory untuk client-side processing sedangkan untuk server-side processing didapatkan hasil dengan rata-rata 960,28 ms kecepatan load data dan 8610 bytes untuk penggunaan memory. Adapun hasil perbandingan kecepatan load data disajikan dalam bentuk grafik yang dapat dilihat pada Gambar 12 .

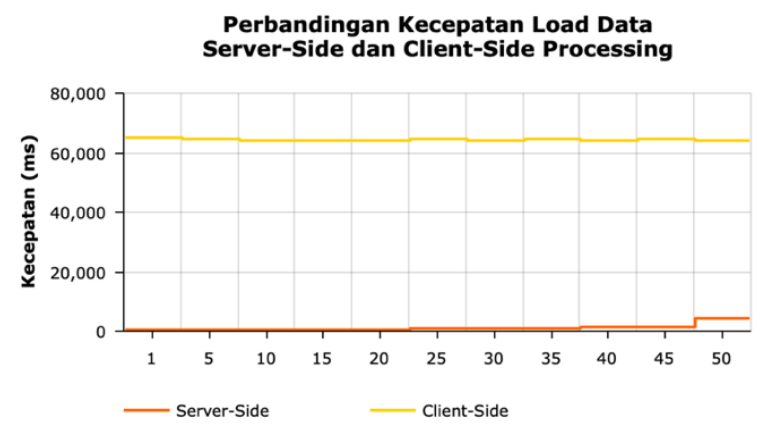

Sumber: (Sulastri et al., 2019)

Gambar 12. Grafik Perbandingan Server dan Client-side Processing

\section{KESIMPULAN}

Penyajian data server-side processing telah berhasil di implementasikan pada aplikasi sederhana dan dilakukan proses perbandingan ukuran dan kecepatan load data dengan client-side processing. Dari hasil pengujian tools menggunakan JMeter terhadap client-side processing dan server-side processing didapat presentase $98,6 \%$ lebih cepat server-side processing dibandingkan client-side processing. Sementara pada penggunaan memory server-side processing lebih kecil 99,6\% dibandingkan dengan client-side processing. Hal tersebut menunjukkan penggunaan teknik serverside processing lebih optimal. Untuk pengembangan teknik server-side processing ini, selanjutnya dapat dicoba menerapkan teknik server-side processing ke dalam proses lain selain DataTables dan proses pengujian menggunakan beberapa server terdistribusi (distributed server).

\section{REFERENSI}

Burd, I. G. S., Us, W. A., Cooper, K. B., Us, W. A., Guthrie, S. D., Us, W. A., ... Us, W. A. (2006). ( 12 ) United States Patent T A 1910, 1(12).

Gartner. (n.d.). What Is Big Data? Gartner IT Glossary - Big Data.

Gope, D., Schlais, D. J., \& Lipasti, M. H. (2017). Architectural Support for Server-Side PHP Processing. ACM SIGARCH Computer Architecture News, 45(2), 507-520. https://doi.org/10.1145/3140659.3080234

Husen, H., Rahmatulloh, A., \& Sulastri, H. (2019). Implementasi Komunikasi Full Duplex Menggunakan Web Socket Pada Sistem Informasi Pengelolaan Anggaran Universitas Abc. Simetris: Jurnal Teknik Mesin, Elektro Dan Ilmu Komputer, 9(1), 603-612.

Kersten, B., \& Goedicke, M. (2010). Browser-based Analysis of Web Framework Applications. Electronic Proceedings in Theoretical Computer Science, 35, 51-62. https://doi.org/10.4204/eptcs.35.5

SpyMedia. (2019). DataTables Examples - Server Side Proccessing. Retrieved from https://datatables.net/examples/server_side

Sulastri, H., Rahmatulloh, A., \& Hidayat, D. K. (2019). Laporan Akhir Penelitian "Server-Side Processing Techniques For Optimizing The Speed Of Presenting Big Data."Jawa Barat.

Wang, D. L., Zender, C. S., \& Jenks, S. F. (2009). Efficient clustered server-side data analysis workflows using SWAMP. Earth Science Informatics, 2(3), 141-155. https://doi.org/10.1007/s12145-009-0021-z

Yannick Saillet, S. (DE). (2013). Server Side Processing Of User Interactions With A Web Browser, 2(12). 